\title{
The Impact of External Business Environment on Corporate Social Responsibility: Theoretical Implications and Empirical Evidence
}

\author{
Yankuo Qiao \\ Rutgers Business School, Rutgers University, Newark, NJ, USA \\ Email: yankuo.qiao@rutgers.edu
}

How to cite this paper: Qiao, Y. K. (2020). The Impact of External Business Environment on Corporate Social Responsibility: Theoretical Implications and Empirical Evidence. Theoretical Economics Letters, 10, 500-522.

https://doi.org/10.4236/tel.2020.103032

Received: April 22, 2020

Accepted: May 24, 2020

Published: May 27, 2020

Copyright ( 2020 by author(s) and Scientific Research Publishing Inc. This work is licensed under the Creative Commons Attribution International License (CC BY 4.0).

http://creativecommons.org/licenses/by/4.0/

\section{(c) (i) Open Access}

\begin{abstract}
The literature evidently demonstrates the CEO-centric effect upon firms' Corporate Social Responsibility (CSR) engagements. Given the CEO's strong discretionary power over CSR decisions and self-serving motive divergent from shareholder value maximization, it would be interesting to investigate the strategic decisions made by the CEO on CSR policy facing varied dimensions of market conditions. From an agency theory perspective, the paper develops a theoretical framework to model and clarify the relationships between firm's CSR provisions and the three dimensions of external market conditions: market complexity, munificence, and dynamism. Furthermore, I empirically measure the market dimensions and test the propositions implied by the theoretical work. Consistent with the model implications, I found CEOs tend to invest more in CSR in a competitive market, less in CSR when the market is munificent and more in CSR when the market is dynamic and unpredictable. The results are consistent with the extant literature and shed light on the value relevancy of CSR activities.
\end{abstract}

\section{Keywords}

External Business Environment, Corporate Social Responsibility, Analytical Modeling, CEO Centric Effect, Agency Theory

\section{Introduction}

It is widely documented that corporate social responsibility (CSR) activities are deeply value relevant (see, for example, Szymanski and Henard, 2001, Godfrey, Merrill, and Hansen, 2009, and Luo and Bhattacharya, 2009). As such, corporate social performance (CSP) becomes an important dimension of firm performance, 
which measures the level of socially responsible provisions. Increasing evidence in the literature suggests that firm's CSR engagements are largely determined by the CEO (see, for example, Fernández-Kranz and Santaló, 2010, Kang, 2017, Brick and Qiao, 2017, and Bernard, Godard, and Zouaoui, 2018). Building upon the value relevancy of CSR and the CEO-centric effect on social activities, the paper steps further to analyze the strategic decision making of CEO in face of different market conditions both theoretically and empirically. In the analytical work of the paper, I develop a comprehensive framework pertaining to the linkage between CEO's propensity of engaging in CSR activities and three orthogonal dimensions of external business environment: market complexity, munificence and dynamism. Whereby making assumptions in accordance with the implications in the literature, I propose testable propositions and hypotheses for the empirical work in this study. Specifically, I find that market complexity or competitiveness has positive net influence on firm's investment in socially responsible activities. Rapidly growing firms operating in industries with abundant resources (thus higher munificence) are less likely to spend their surplus on benevolent purpose. Moreover, firms facing turbulent market conditions are more likely to engage in social responsibility activities which are in line with the evidence demonstrated in Barney (1991), Wernerfelt (1984), and Godfrey, Merrill, and Hansen (2009).

The paper contributes to both the literature on CSR value relevancy (see, for example, Szymanski and Henard, 2001, Godfrey, Merrill, and Hansen, 2009, and Luo and Bhattacharya, 2009) and the literature on CEO centric effect (see, for example, Fernández-Kranz and Santaló, 2010, Kang, 2017, Brick and Qiao, 2017, and Bernard, Godard, and Zouaoui, 2018). From agency theory perspective, the paper introduces the moderating effect of external business environment on the linkage between CEO and CSR activities, whereby theoretically illustrating and empirically verifying that $\mathrm{CEO}$ and top executives tend to strategically utilize CSR activities in face of varied business environments. The paper also contributes to the strand of literature on market competition and CSR provisions (see, for example, Bagnoli and Watts, 2003, Fisman, Heal, and Nair, 2006, and Fernández-Kranz and Santaló, 2010) whereby expanding the market conditions to multiple dimensions. Moreover, the theoretical framework developed by the paper is seminal in the sense that with further specializations, the framework is an ideal platform to model how the CSR provisions will react in face of either external profitability shocks or internal managerial turnovers.

The structure of the research is organized as follows: Section 2 presents the literature and theoretical background which provides motivation for the development of the analytical framework. Centered at the strategic decision making of CEO, Section 3 develops the theoretical framework that models the relationships between CSR provisions of the firm and the three dimensions of external business environment. According to the derived propositions, three testable hypotheses are given in this section. Section 4 describes the data, constructs empirical metrics and formulates econometric models to test the corresponding hypo- 
theses. Section 5 summarizes the statistical tests and performs analyses on the empirical results in accordance with the theory and hypotheses. Section 6 gives concluding remark on the significance of the study and a brief outlook on the future study.

\section{Literature}

\subsection{Environmental Dimensions}

Rather than focusing mainly on the production market competition as in classic finance and economics literature, the organizational management literature has rigorous development on the environmental dimensions of external business conditions facing the firm (see, for example, Aldrich, 1979; Dess and Beard, 1984; and Keats and Hitt, 1988). According to the literature, those dimensions are theoretically defined as munificence, instability and complexity. Munificence or environmental capacity refers to the abundance of environmental resources and resulting capacity to support growth. Instability or dynamism reflects volatility or difficult-to-predict discontinuities in the dominant industry of a firm. Complexity or market competition represents the heterogeneity and concentration of environmental elements. Williamson (1965), Khandwalla (1973) and Starbuck (1976) suggest that the industries demonstrating high monopoly power are less complex than those demonstrating less monopoly power. The literature has documented that the environmental context of the dominant industry affects firm-level strategies (Hill and Hoskisson, 1987; Hitt and Ireland, 1985).

\subsection{Strategic Provisions of CSR}

Extensive research attentions are also paid to addressing the relation between product market competition and CSR expenditures both theoretically and empirically (see, for example, Bagnoli and Watts, 2003; Fisman, Heal, and Nair, 2006; Fernández-Kranz and Santaló, 2010; and Zhang, Zhu, Yue, and Zhu, 2010). The theories are divided. The signaling model in Fisman, Heal, and Nair (2006) shows that CSR provisions in private goods serves as a vertical differentiation tool in product market. Thus, in the separating equilibrium, socially responsible firms provide more CSR provisions in face of higher product market competition. However, in a pooled equilibrium, Bagnoli and Watts (2003) show that higher market competition (e.g. Bertrand price competition) leads to less than efficient amount of public goods provided in the private products since facing highly competitive market condition and shrinking profit margin, firms are incapable of carrying the additional costs incurred by CSR. Attempting to reconcile the literature, the model in Fernández-Kranz and Santaló (2010) shows that the net influence of competition on CSR depends on the tradeoff between the "marginal effect" and "business stealing effect", and thus depends on how the competition and demand function is modeled. Interestingly, both of the two opposing papers illustrate that in competition for socially responsible customers, 
firms tend to provide more public goods. It is also consistent with the evidence in Zhang, $\mathrm{Zhu}, \mathrm{Yu}$, and $\mathrm{Zhu}$ (2010) that corporate philanthropic giving is positively related to advertising intensity.

\subsection{Value Relevancy of CSR}

It is widely documented in the literature that CSR activities are value relevant. Firms are motivated to engage in social responsibility activities mainly to enhance customer satisfaction, build up intangible assets and goodwill, and stabilize financial conditions. Specifically, whereby improving customer satisfaction, socially responsible firms are more likely to enjoy higher customer loyalty (see, for example, Oliver, 1980 and Bolton and Drew, 1991), receive higher reviews and evaluations (Brown and Dacin, 1997 and Szymanski and Henard, 2001) and eventually are able to charge premium price. Prior studies have documented that the reputation and the socially positive image earned by the firm through proactively engaging in CSR provisions could be transferred to intangible assets and goodwill, leading to premium valuation (see, for example, McWilliams and Siegel, 2001 and Luo and Bhattacharya, 2009). In face of external profit shocks, socially responsible firms are more likely to achieve financial stabilization and higher market value, according to the studies of resource-based theories (see, for example, Barney, 1991 and Wernerfelt, 1984). In addition, firm is less likely to face accusations, filing complains, investigation and legal litigation especially in market depression period (Godfrey, Merrill, and Hansen, 2009).

\subsection{Agency Problem}

Agency theory tells us that unless CEO is the sole owner of the firm, the incentive of CEO shall always deviate from shareholder value maximization (see, for example, Berle and Means, 1932 and Jensen and Meckling, 1979). Provided that CSR is value relevant, CEO is likely to strategically utilize CSR to maximize her own utility according to the external market conditions. Thus, the theoretical modeling in the following section is centered at the utility optimization of CEO herself.

\section{The Model}

Based on the empirical evidence in Brick and Qiao (2017) and Bernard, Godard, and Zouaoui (2018), and the model in Fernández-Kranz and Santaló (2010), I develop a comprehensive framework about CEO's strategic decisions on CSR in face of external business environments. Albeit by no means a fully-fledged theoretical model, the following analytical development organizes the mechanisms behind the scenes in a synthetic manner and leads to the empirically testable hypotheses on the basis of comparative statics.

Suppose one industry or a particular market has $\mathrm{n}$ firms. The profit $\left(\pi_{i}\right)$ of a socially responsible firm $i$ can be represented as follows.

$$
\pi_{i}=\left(P_{i}-C_{i}\right) X\left(P_{1}, P_{2}, \cdots, P_{i}, \cdots, C S P_{i}, \cdots, C S P_{n}\right)-C\left(C S P_{i}\right)-F_{i}
$$


in which $P_{i}$ is the price, $C_{i}$ is the constant marginal cost, $C S P_{i}$ stands for corporate social performance, $X(*)$ is the amount of products sold and is a function of price and CSR provisions of its own firm, and of price and CSR provisions of other firms in the market, $C\left(C S P_{i}\right)$ represents CSR expenditures and $F_{i}$ is the fixed cost of the firm. Specifically, $P_{i}-C_{i}$ denotes the marginal profit of the firm and is negatively related to the competition. $X(*)$ increase in CSP $_{i}$ (see, for example, Fisman, Heal, and Nair, 2006 and Fernández-Kranz and Santaló, 2010), and I assume the incremental value is decreasing (concave curvature) according to the classic economic setting of diminishing marginal effect. Further, consistent with the typical form of cost function, cost of CSR expenditures $C\left(C S P_{i}\right)$ is a monotonically increasing convex function with respect to level of CSR provisions, i.e., $C^{\prime}>0$ and $C^{\prime \prime}>0$ (WLOG, I can also assume the marginal cost is constant $C^{\prime \prime}=0$ ).

According to Brick and Qiao (2017) and Bernard, Godard, and Zouaoui (2018), CSR expenditures are largely subject to CEO's discretionary power. Thus, the strategic decision making of CEO is the central part of modeling CSR provisions and business environment. The total compensation ( $w$ ) of CEO is structured as follows.

$$
w=a+b \pi_{i}+\varepsilon_{i}
$$

in which $a$ is the base salary, positively related to the current level of market munificence, $b$ represents the performance sensitive bonus and $\varepsilon_{i}$ denotes the random compensation shocks due to the uncertainty of the external business environment. Here I adopt the arguments of weak rational expectation (see, for example, Muth, 1961, and Lovell, 1986) in the way that $\varepsilon_{i}$ represents a complete innovation term to the CEO and thus is exogenous to other component of CEO compensation. As such, $\varepsilon_{i}$ is a pure white noise, and is normally and independently distributed. The only prior knowledge of CEO as of making strategic decisions on CSR engagements is about the distribution of $\varepsilon_{i}$, but not about any potential realizations. The distribution of $\varepsilon_{i}$ is clearly a reflection of the current level of market dynamism. Specifically, $\varepsilon_{i}$ is assumed to follow a demeaned Gaussian distribution, $N\left(0, \sigma_{i}^{2}\right)$, in which $\sigma_{i}^{2}$, as the sole factor parametrizing the distribution function, is endogenous to the current level of market dynamism facing the company and is negatively moderated by CSR provisions (stabilization effect of CSR, see, for example, Barney, 1991, Wernerfelt, 1984, and Godfrey, Merrill, and Hansen, 2009).

Assume the CEO has a constant absolute risk aversion (CARA) utility function as follows,

$$
U\left(w_{i}\right)=-\mathrm{e}^{-\lambda_{i} w_{i}}
$$

in which $w_{i}$ is the total income of the CEO in face of the current environmental conditions and $\lambda_{i}$ is the absolute risk aversion of the CEO and is determined by the CEO's current risk propensity. I further assume that the risk preference of the CEO is changing along with the variation of CEO's wealth, firm performance and 
growth potential, and external market conditions. Specifically,

$$
w_{i}=a+b \pi_{i}+\varepsilon_{i}=a+b\left(\left(P_{i}-C_{i}\right) X\left(\cdots C S P_{i} \cdots\right)-C\left(C S P_{i}\right)-F\right)+\varepsilon_{i}
$$

For simplicity and without loss of generality, let $b=1, a=F$ and $w_{i}=\left(P_{i}-C_{i}\right) X(*)-C\left(C S P_{i}\right)+\varepsilon_{i} \sim N\left(\bar{w}_{i}, \sigma_{i}^{2}\right)$. The strategic decision made by CEO on CSR expenditures can then be represented using the following optimization program.

$$
\max _{C S P} E\left(U\left(w_{i}\right)\right)=E\left(-\exp \left(-\lambda w_{i}\right)\right)
$$

Applying moment generating function (MGF), the above program is transformed as follows,

$$
\begin{aligned}
\max _{C S P} E\left(U\left(w_{i}\right)\right) & =E\left(-\exp \left(-\lambda_{i} w_{i}\right)\right)=-\exp \left(-\lambda_{i}\left(\bar{w}_{i}-\frac{1}{2} \lambda_{i} \sigma_{i}^{2}\right)\right) \\
& =-\exp \left(-\lambda_{i}\left(\left(\left(P_{i}-C_{i}\right) X(*)-C\left(C S P_{i}\right)\right)-\frac{1}{2} \lambda_{i} \sigma_{i}^{2}\right)\right)
\end{aligned}
$$

Equivalently,

$$
\max _{C S P} E\left(U\left(w_{i}\right)\right) \Leftrightarrow \max _{C S P}\left(P_{i}-C_{i}\right) X\left(\cdots C S P_{i} \cdots\right)-C\left(C S P_{i}\right)-\frac{1}{2} \lambda_{i} \sigma_{i}^{2}
$$

Therefore, the FOC condition is as follows,

$$
\begin{aligned}
& \left(P_{i}-C_{i}\right) \frac{\partial X}{\partial C S P}-\frac{\partial C_{c s p}}{\partial C S P}+\lambda_{i}\left(-\frac{1}{2} \frac{\partial V}{\partial C S P}\right)=0 \\
& \Leftrightarrow\left(P_{i}-C_{i}\right) \frac{\partial X}{\partial C S P}+\lambda_{i}\left(-\frac{1}{2} \frac{\partial V}{\partial C S P}\right)=\frac{\partial C_{c s p}}{\partial C S P}
\end{aligned}
$$

in which $V=\sigma^{2}$, denotes the variance of CEO's income uncertainty to simplify the notation. The optimal level of CSR provisions chosen by the CEO in frim $i$ solves the above first order condition for the partial equilibrium. According to the extant literature on environmental dimensions and the value relevancy of CSR, the resulting equilibria is dependent on the parameters of external business environment: complexity or competition $(\kappa)$, munificence $(\mu)$ and dynamism $(\theta)$, and their relationships with the socially responsible activities undertaken by the firm. To clearly address the partial effect of each orthogonal environmental dimensions, for each firm $i$, I explicitly parametrize the differential equation of FOC as following.

$$
(P(\kappa)-C) \frac{\partial X}{\partial C S P}(\kappa)+\lambda(\mu)\left(-\frac{1}{2} \frac{\partial V}{\partial C S P}(\theta)\right)=\frac{\partial C_{c s p}}{\partial C S P}
$$

Albeit without specializing the functional structures, several important implications can be drawn from the above general framework, in which the endogenous relation between each component and external parameters of business condition is explicitly denoted in the reduced form of comparative statics. In accordance with assumptions based on theoretical implications and empirical evidence in the extant literature, the following analytical process leads us to testable propo- 
sitions for empirical studies. First off, the first component in the FOC, $(P(\kappa)-C) \frac{\partial X}{\partial C S P}(\kappa)$ captures the two contradictory effects of market complexity. More environmental complexity indicates low market concentration and high competition, which decreases the marginal profit of the firm, $(P(\kappa)-C)$. On the other hand, according to the argument in Fernández-Kranz and Santaló (2010), provisions of CSR has "business stealing effect" in the sense that due to the warm glow altruism valued by consumers (Andreoni, 1989, 1990), $X(*)$ will increase in CSR provisions and this business stealing effect will become more severe in the more competitive market with more necessity of product differentiation, $\frac{\partial^{2} X}{\partial C S P \partial \kappa}>0$. Thus, accounting for the integration of the negative marginal effect and the positive business stealing effect, the net influence of environmental complexity becomes an empirical problem. Moreover, as widely mentioned in the above literature (see, for example, Bagnoli and Watts, 2003 and Zhang, Zhu, Yu, and Zhu, 2010), advertising intensity represents the consumers participation value and therefore increase the positive magnitude of $\frac{\partial^{2} X}{\partial C S P \partial \kappa}$, shifting the net influence of market complexity to the positive side.

Assumption 1.a: The business stealing effect motivated by the warm glow altruism valued by customers become increasingly influential when the market is more competitive and of more complexity, or $\frac{\partial^{2} X}{\partial C S P \partial \kappa}>0$.

Proposition 1.a: Ceteris paribus, the net influence of market dimension of complexity on the CSR provision is dependent on the magnitude of business stealing effect and marginal profit effect.

Assumption 1.b: The sensitivity of the customer's reaction to the business increase in the advertising intensity of the industry.

Proposition 1.b: Ceteris paribus, the aggregate effect of market complexity on the CSR provision is more likely to be positive when the advertising intensity of the industry is high.

Secondly, $\lambda(\mu)\left(-\frac{1}{2} \frac{\partial V}{\partial C S P}(\theta)\right)$, the second component in the FOC captures the effects of environmental munificence $(\mu)$ and dynamism $(\theta)$. Specifically, when the external business environment has been experiencing rapid growth for years, the wealth of the CEO is rising due to the accrued incentive pays over years and the risk averse propensity of the CEO could be cushioned by the abundant resources of slack money. Furthermore, the CEO is more likely to hold optimistic perspective for the future development of the business and the degree of over-confidence inherent in her characteristics will be exaggerated, resulting in hard-driving managerial style in the context of decision making and policy implementation. Thus, the CEO is willing to take more risk as to making investment decisions on aggressive projects and $\lambda_{i}$ is decreasing. Since $\frac{\partial \lambda}{\partial \mu}<0$ and muni- 
ficence has negative effect on the second component $\lambda(\mu)\left(-\frac{1}{2} \frac{\partial V}{\partial C S P}(\theta)\right)$, CSR expenditures would decrease in munificence holding other factors constant. This negative relationship between risk aversion and abundancy of endowments is also evidently demonstrated in Guiso and Paiella (2008) using unique survey data.

Assumption 2: The risk aversion of CEO is negatively related to the generosity of external business resources and abundancy of growth opportunity measured by environmental munificence, or $\frac{\partial \lambda}{\partial \mu}<0$.

Proposition 2: Ceteris paribus, the effect of environmental munificence is negative on the level of CSR provisions chosen by the CEO, or $\frac{\mathrm{d} C S P}{\mathrm{~d} \mu}<0$.

Finally, due to the stabilization effect of CSR (Barney, 1991; Wernerfelt, 1984; Godfrey, Merrill, and Hansen, 2009), the volatility of CEO's income brought by the market uncertainty will decrease in CSR provisions $\left(-\frac{1}{2} \frac{\partial V}{\partial C S P}\right)>0$ and the sensitivity of $V$ to CSR provisions is higher in more dynamic industries in the sense that when the environmental uncertainty is naturally high, firms with good social reputation would avoid more negative shocks than the same firm but in a stable business environment, $\left(-\frac{1}{2} \frac{\partial^{2} V}{\partial C S P \partial \theta}\right)>0$. Analogous to the business stealing effect, the stabilization effect is expected to be more effective in the highly dynamic environment, leading to more expenditure on CSR. Obviously, the CSR provisions are more demanding in dynamic industries facing frequent negative shocks.

Assumption 3: The stabilization of effect of CSR provisions become increasingly effective when the environmental dynamism is higher, $\left(-\frac{1}{2} \frac{\partial^{2} V}{\partial C S P \partial \theta}\right)>0$.

Proposition 3: Ceteris paribus, the influence of environmental dynamism on the level of CSR provisions chosen by the CEO is positive, or $\frac{\mathrm{d} C S P}{\mathrm{~d} \theta}>0$.

The complete derivation of the above propositions using comparative statics is fleshed out in the appendix. In sum, based on the above theoretical work and testable propositions, I develop the following hypotheses to guide the empirical tests. Note that according to the assumptions associated with Proposition 1, the linkage between market complexity and CSR provisions is moderated by the advertising intensity. In addition to type II error, any potential negative results of the following hypotheses could be attributed to the fact that the underlying assumptions associated with propositions are not empirically valid.

H1: Market complexity is positively (negatively) related to CSR provisions.

$\mathrm{H} 2$ : Market dynamism is positively related to CSR provisions.

H3: Market munificence is negatively related to CSR provisions.

To empirically verify the above hypotheses proposed in accordance with the 
implications of the theoretical framework, I choose to use fixed effect models (FE) to perform a battery of regression analyses on panel dataset. Serving as the main identification strategy, the high dimensional fixed effects capture industry, firm and CEO level unobservable and time-invariant heterogeneity that are implicitly embedded in the modeling framework. The general form of the regression model is structured as follows:

$$
C S P_{i t}=\beta_{0}+\beta_{1}^{\prime} z_{i, t}+\beta_{2}^{\prime} x_{i, t-1}+\lambda_{t}+\gamma_{k}+C E O_{j}+\varepsilon_{i t}
$$

in which $z$ is a vector of three dimensions of external market conditions: complexity, munificence, and dynamism; $x$ is a vector of fundamental covariates; $\lambda_{t}$ and $\gamma_{k}$ represents year fixed effect and industry fixed effect, respectively ; $C E O_{j}$ is $\mathrm{CEO}$ or CEO-firm joint fixed effect. To ward off potential reversed causality, all the firm characteristics are dated at the beginning of the year. Year fixed effect, $\lambda_{t}$ is included in the model specification to control for macro-economic conditions. Depending on the model specification, I perform regression analyses using either $\mathrm{CEO}$ fixed effect or CEO-firm joint fixed effect for comparison and robustness. The data and specific construction of the metrics are detailed in Section 4 and the empirical results are summarized in Section 5 .

\section{Measures, Data and Methodology}

\subsection{Environmental Dynamism and Munificence}

Regressing the logarithm of industrial sales against year, I have a model in time-series manner of 5 years rolling window as follows,

$$
Y_{t}=\beta_{0}+\beta_{1} t+\varepsilon_{t}
$$

in which $Y_{t}$ is the logarithm transferred industrial sales and $t$ is year. According to Keats and Hitt (1988), the volatility of sales over every five years, measured as the antilog of standard error of regression slope coefficient (STD), is used as proxy for industrial dynamism. Similarly, the average growth of industry sales over every 5 years, measured as the antilog of regression slope coefficient (COEFF), is used as proxy for industrial munificence.

\subsection{Environmental Complexity}

As suggested by Williamson (1965), Khandwalla (1973) and Starbuck (1976), the industries demonstrating high monopoly power are less complex than those demonstrating less monopoly power. Herfindahl-Hirschman index or HHI is extensively used in literature on measuring the rate of industrial concentration and on the level of monopoly. The level of market competitiveness is in fact interchangeable to market complexity in this context. A higher HHI indicates lower level of market competitiveness and thus lower level of market complexity. HHI is computed by summing up the squared market shares of each firm. In accordance with Keats and Hitt (1988) the complexity represents the competition structure in the market, which is closely related to HHI. I use one minus $\mathrm{HHI}$ as a proxy for environmental complexity (see, for example, Fang, Palmatier, 
and Steenkamp, 2008).

\subsection{Measures of Corporate Social Performance (CSP)}

Another methodological concern is how to construct a comprehensive measure of CSR with sufficient validity and reliability. For the sake of capturing the overall performance of CSR in a broad scope, I measure the level of social-friendly activities conducted by the firm using data from KLD Research \& Analytics, Inc. SOCRATES database. KLD net scores, as the most general and popular measures for CSR performance, assign ratings for up to thirteen dimensions. To focus on the CEO's skills or managerial styles for stakeholder management, I select seven major dimensions to construct the proxy: product quality and safety, environment, governance, employee relations, diversity, community relations and human rights investment, each specifying a linkage between the firm and internal or external stakeholders. The scores are assigned by sector analyst under the proprietary framework based on a wide variety of data sources across company filings, government and nongovernment data, public media sources and direct communication or survey through connections with executives of the company. The sum of KLD net scores summarizes quite well the social activities of the firm and is widely used by the literature (see for example, Lins, Servaes, and Tamayo, 2017). It is noteworthy that in SOCRATES database, the KLD scores are not completely assigned to each dimension in each year. Therefore, in order to make KLD scores comparable throughout different years and increase the efficiency of parameter estimates in the regression analyses, I scale the sum of KLD scores by the number of dimensions rated in the year, generating the fraction of the original measure, as is shown below. The measures based on KLD scores to gauge the CSR activities of the firm are widely used or modified by the literature, for example, Agle, Mitchell, and Sonnenfeld, 1999; Deckop, Merriman, and Gupta, 2006 and Bae, Kang, and Wang, 2011. In particular, I compute the scaled KLD score using the following formula:

$$
K L D_{i t}=\frac{1}{K_{t}} \sum_{k}^{K_{t}}\left(\frac{1}{S_{t}^{k}} \sum_{s}^{S_{t}^{k}} \text { Strength }_{i t s}^{k}-\frac{1}{C_{t}^{k}} \sum_{c}^{C_{t}^{k}} \text { Concern }_{i t c}^{k}\right)
$$

in which $K L D_{i t}$ is the CSP metrics for firm $i$ in year $t, S_{t}^{k}$ is the number of strength items in year $t$ for dimension $k, C_{t}^{k}$ is the number of concern items in year $t$ for dimension $k, K_{t}$ is the number of dimensions in the year, and Strength $h_{i t s}^{k}$ and Concern $_{i t c}^{k}$ are scores of strength and concern items in in year $t$ for dimension $k$, respectively.

\subsection{Other Control Variables of CEO and Firm Characteristics}

Besides the above explanatory variables with specific moderating effects of interest, I also include other firm-based control variables in the econometric specification of the multivariate regression analysis. I use Compustat data to obtain 
data of total assets (AT), market leverage ratio (LEVERAGE), market to book ratio $(\mathrm{MB})$, research and development expenditure ( $\mathrm{R} \& \mathrm{D})$ ), tangibility (PP \& E) and return on assets (ROA) to depict the firm characteristics in various aspects such as firm scale and complexity, growth opportunity, solvency, and profitability. I also obtain data of firm characteristics, such as advertisement expenses (ADV), corporate marginal tax rates (MTR), and level of excess accruals (EXACCR), which are recognized as determinants of corporate social performance (CSP) in the extant literature (see, for example, McWilliams and Siegel, 2001, Udayasankar, 2008, Cordeiro and Tewari, 2015). In order to remove the firm's size effect on variables such as R \& D and ADV for intensity, I further modify those variables by scaling them by total assets. AT is taken logarithm to account for the skewness of sampling distribution. The detailed explanation and data sources are summarized in Table 1.

\section{Results and Analyses}

Table 2 reports the empirical results of regressing the weighted sum of KLD scores on the measures of three orthogonal dimensions of external environment conditions, market complexity, munificence and dynamism, while controlling for other firm level covariates.

The coefficients of external market measures are statistically significant at $1 \%$ and are in alignment with the arguments in the hypotheses drawn from the theoretical framework of the CEO's strategic decision making on CSR engagements in face of different external conditions. Specifically, in column 1, the coefficient of market complexity, $\mathrm{HHI}$, is negative and significant at $1 \%$, indicating that market competitiveness has positive net influence on firm's investment in socially responsible activities. The coefficient of market munificence measure (COEFF) is negative and significant at $1 \%$, indicating rapidly growing firms operating in industries with abundant resources are less likely to spend their surplus on benevolent purpose. The coefficient of market dynamism measure (STD) is positive and significant at $1 \%$, suggesting that firms facing turbulent market conditions are more likely to engage in socially responsible activities, which is in line with the evidence demonstrated in Barney (1991), Wernerfelt (1984), and Godfrey, Merrill, and Hansen (2009). These empirical results are robust to the inclusion of industry dummies by different classifications, such as Fama-French 12 industry portfolios (FF12), Fama-French 49 industry portfolios (FF49) and 4-digit Standard Industry Classification (SIC). Moreover, given the CEO-centric effect on CSR as evidently demonstrated in Kang (2017), Brick and Qiao (2017) and Bernard, Godard, and Zouaoui (2018), I also include dummies for CEO fixed effect in the model specification. The CEO dummies capture the unobservable individual effect of CEO, which is arguably related to key parameters in the modeling, such as risk aversion and private knowledge about the disturbance of market shocks. Whereby controlling the endogenous individual effect of CEO, the coefficients of market conditions reflect the true effect of market dimension 
accounting for heterogeneous managerial traits and skills of CEOs. Notably, the influence of external market conditions stays unchanged statistically and the adjusted $\mathrm{R}$ squared for the specification with CEO fixed effects are much higher than those without, confirming the CEO-centric influence on CSR, which is in turn the foundation for the model development.

The primary findings of the empirical test are also robust to heteroscedastic standard error (Table 3 ), as well as using only main covariates (Table $4 \&$ Table $5)$, in which much more data are employed in the empirical test. Further note that when using less firm covariates, the model includes CEO-firm linked fixed effects to capture unobservable heterogeneity in more granular level.

Table 1. Variable definition and data source.

\begin{tabular}{|c|c|c|}
\hline Variable & Explanation & Source \\
\hline CSP & $\begin{array}{l}\text { As a general measure of the corporate social performance in } \\
\text { the paper, I form it by adding up scaled KLD net scores in } \\
\text { SOCRATES database across all } 7 \text { dimensions: product quality } \\
\text { and safety, environment, employee relations, corporate } \\
\text { governance, diversity and community relations. I further scale } \\
\text { the sum by the number of scored dimensions each year for the } \\
\text { empirical analysis. }\end{array}$ & $\begin{array}{l}\text { KLD Research \& } \\
\text { Analytics, Inc. }\end{array}$ \\
\hline $\mathrm{AT}$ & Logarithmic total assets & Computstat \\
\hline MB & Market value of equity/book value of equity & Computstat \\
\hline LEVERAGE & Long-term debt/(total debt + market value of equity) & Compustat \\
\hline PP \& E & Fixed assets/total assets & Compustat \\
\hline $\mathrm{R} \& \mathrm{D}$ & Firm size adjusted research and development expense & Compustat \\
\hline ROA & Net Income/total assets & Compustat \\
\hline ADV & Advertising expenses scaled by total assets & Compustat \\
\hline EXACCR & $\begin{array}{l}\text { Proxy for the firm's willingness to engage in earnings } \\
\text { management. The proxy is calculated by subtracting the average } \\
\text { level of accruals used by the firm's industry from the level of } \\
\text { accruals scaled by the firm's total assets, in which accruals are } \\
\text { defined as the difference between net income and cash from } \\
\text { operations. }\end{array}$ & Compustat \\
\hline MTR & $\begin{array}{l}\text { Marginal tax rate is the amount of tax paid on one more dollar } \\
\text { of income, which is the proxy for the cost of investment in CSR in } \\
\text { terms of after-tax dollars. }\end{array}$ & $\begin{array}{l}\text { Via the website } \\
\text { of John Graham }\end{array}$ \\
\hline HHI & $\begin{array}{l}\text { The Herfindahl-Hirschman index is a proxy for market } \\
\text { complexity (e.g., Keats and Hitt, 1988), which is calculated by the } \\
\text { sum of squared companies' net sales over the squared main } \\
\text { industry sales to which the companies belong. }\end{array}$ & Compustat \\
\hline COEFF & $\begin{array}{l}\text { The coefficient of regressing logarithmic industry sales on the } \\
\text { fiscal year, using data of every five years (e.g., Keats and Hitt, } \\
\text { 1988). It is a proxy for market munificence, indicating the average } \\
\text { growth rate of industrial sales over five years. }\end{array}$ & Compustat \\
\hline STD & $\begin{array}{l}\text { This is the standard error of the coefficient generated from the } \\
\text { above regression, which is a proxy for market dynamism. }\end{array}$ & Compustat \\
\hline
\end{tabular}


Table 2. CSP and external market conditions by OLS controlling for full covariates.

\begin{tabular}{|c|c|c|c|c|c|c|}
\hline & \multicolumn{6}{|c|}{ OLS } \\
\hline & (1) & (2) & (3) & (4) & (5) & (6) \\
\hline \multirow[t]{2}{*}{ HHI } & $-0.225^{\star * *}$ & $-0.230^{* * *}$ & $-0.235^{\star * *}$ & $-0.078^{\star * *}$ & $-0.149^{* * *}$ & $-0.285^{\star * *}$ \\
\hline & $(-3.109)$ & $(-3.130)$ & $(-3.174)$ & $(-2.824)$ & $(-5.008)$ & $(-3.997)$ \\
\hline \multirow[t]{2}{*}{ COEFF } & $-0.056^{\star *}$ & $-0.055^{\star *}$ & $-0.055^{\star *}$ & $-0.127^{\star * *}$ & $-0.137^{\star \star \star}$ & $-0.084^{\star * *}$ \\
\hline & $(-2.351)$ & $(-2.281)$ & $(-2.280)$ & $(-6.593)$ & $(-7.177)$ & $(-3.785)$ \\
\hline \multirow[t]{2}{*}{ STD } & $0.219^{\star * *}$ & $0.226^{\star * *}$ & $0.223^{\star * *}$ & $0.132^{\star * *}$ & $0.186^{* * *}$ & $0.190^{\star * *}$ \\
\hline & (5.003) & $(5.152)$ & (5.084) & (3.894) & (5.527) & (5.028) \\
\hline \multirow[t]{2}{*}{$\mathrm{AT}$} & $-0.042^{* * *}$ & $-0.051^{* * *}$ & $-0.047^{\star * *}$ & $0.057^{\star * *}$ & $0.071^{\star * *}$ & $0.089^{* * *}$ \\
\hline & $(-2.587)$ & $(-3.032)$ & $(-2.746)$ & $(15.084)$ & (17.68) & $(20.087)$ \\
\hline \multirow[t]{2}{*}{ MB } & $-0.006^{* * *}$ & $-0.006^{* * *}$ & $-0.007^{\star * *}$ & $0.004^{\star *}$ & $0.006^{\star * *}$ & 0.001 \\
\hline & $(-2.586)$ & $(-2.732)$ & $(-2.836)$ & $(2.233)$ & $(2.782)$ & $(0.544)$ \\
\hline \multirow[t]{2}{*}{ LEVERAGE } & $-0.214^{* * *}$ & $-0.210^{* * *}$ & $-0.203^{\star * *}$ & $-0.232^{\star * *}$ & $-0.216^{\star * *}$ & $-0.214^{\star * *}$ \\
\hline & $(-6.401)$ & $(-6.276)$ & $(-6.071)$ & $(-6.781)$ & $(-6.421)$ & $(-6.487)$ \\
\hline \multirow[t]{2}{*}{ PP \& E } & $-0.140^{* *}$ & $-0.146^{\star *}$ & $-0.151^{\star *}$ & $-0.103^{* * *}$ & -0.035 & 0.03 \\
\hline & $(-2.212)$ & $(-2.289)$ & $(-2.351)$ & $(-3.589)$ & $(-1.086)$ & $(0.786)$ \\
\hline \multirow[t]{2}{*}{$\mathrm{R} \& \mathrm{D}$} & $-0.524^{\star *}$ & $-0.561^{\star *}$ & $-0.511^{\star *}$ & $0.926^{* * *}$ & $0.416^{* * *}$ & 0.221 \\
\hline & $(-2.379)$ & $(-2.541)$ & $(-2.312)$ & $(7.911)$ & (3.017) & (1.5) \\
\hline \multirow[t]{2}{*}{ ROA } & -0.086 & -0.09 & -0.094 & $0.292^{\star * *}$ & $0.250^{* * *}$ & $0.196^{\star * *}$ \\
\hline & $(-1.319)$ & $(-1.381)$ & $(-1.445)$ & (4.774) & (4.139) & $(3.271)$ \\
\hline \multirow[t]{2}{*}{$\mathrm{ADV}$} & -0.111 & -0.112 & -0.16 & $0.884^{* * *}$ & $0.461^{* * *}$ & $0.376^{* *}$ \\
\hline & $(-0.367)$ & $(-0.370)$ & $(-0.471)$ & $(6.414)$ & $(3.221)$ & $(2.398)$ \\
\hline \multirow[t]{2}{*}{ EXACCR } & $0.199^{\star * *}$ & $0.196^{\star * *}$ & $0.193^{* * *}$ & $0.072^{\star \star \star}$ & $0.147^{\star * *}$ & $0.181^{\star * *}$ \\
\hline & (4.599) & $(4.516)$ & $(4.457)$ & (3.458) & $(6.511)$ & $(7.663)$ \\
\hline \multirow[t]{2}{*}{ MTR } & $0.106^{* *}$ & $0.105^{* *}$ & $0.103^{* *}$ & $0.059^{*}$ & $0.080^{* *}$ & $0.120^{* * *}$ \\
\hline & (2.519) & $(2.489)$ & $(2.437)$ & $(1.701)$ & $(2.315)$ & $(3.424)$ \\
\hline CEO FE & YES & YES & YES & NO & NO & NO \\
\hline Industry FE & FF12 & FF49 & 4-digit SIC & FF12 & FF49 & 4-digit SIC \\
\hline Year FE & YES & YES & YES & YES & YES & YES \\
\hline Adj. $R^{2}$ & 0.683 & 0.684 & 0.685 & 0.127 & 0.174 & 0.271 \\
\hline $\mathrm{N}$ & 12,992 & 12,992 & 12,992 & 12,992 & 12,992 & 12,992 \\
\hline
\end{tabular}

Table 2 exhibits the regression results of the relationship between corporate social policy and external market condition using OLS and controlling full covariates. The dependent variable is the weighted sum of KLD scores. The data used for the regressions consist of observations of firms covered by KLD Research \& Analytics, Inc. (KLD) SOCRATES database over the period between 1995 and 2013. The t-statistics are in the parentheses denoted by ${ }^{* * *},{ }^{* *}$ and ${ }^{\star}$ for the significance levels at the $1 \%, 5 \%$ and $10 \%$, respectively. 
Table 3. CSP and external market conditions by HCSE controlling for full covariates.

\begin{tabular}{|c|c|c|c|c|c|c|}
\hline & \multicolumn{6}{|c|}{ HCSE } \\
\hline & (1) & (2) & (3) & $(4)$ & (5) & (6) \\
\hline \multirow[t]{2}{*}{$\mathrm{HHI}$} & $-0.225^{\star * *}$ & $-0.230^{\star * \star}$ & $-0.235^{\star \star \star}$ & $-0.078^{\star * *}$ & $-0.149^{\star * \star}$ & $-0.285^{\star * *}$ \\
\hline & $(-3.051)$ & $(-3.065)$ & $(-3.084)$ & $(-2.627)$ & $(-4.807)$ & $(-4.504)$ \\
\hline \multirow[t]{2}{*}{ COEFF } & $-0.056^{\star *}$ & $-0.055^{\star *}$ & $-0.055^{\star \star}$ & $-0.127^{\star \star \star}$ & $-0.137^{\star \star \star}$ & $-0.084^{\star * *}$ \\
\hline & $(-2.170)$ & $(-2.110)$ & $(-2.104)$ & $(-5.504)$ & $(-5.902)$ & $(-3.328)$ \\
\hline \multirow[t]{2}{*}{ STD } & $0.219^{* * *}$ & $0.226^{\star * *}$ & $0.223^{\star * *}$ & $0.132^{\star * *}$ & $0.186^{\star * *}$ & $0.190^{\star * *}$ \\
\hline & $(4.601)$ & $(4.752)$ & $(4.67)$ & (3.159) & $(4.416)$ & $(4.162)$ \\
\hline \multirow[t]{2}{*}{$\mathrm{AT}$} & $-0.042^{* *}$ & $-0.051^{\star * *}$ & $-0.047^{\star *}$ & $0.057^{\star * *}$ & $0.071^{\star * *}$ & $0.089^{* * *}$ \\
\hline & $(-2.222)$ & $(-2.620)$ & $(-2.365)$ & (11.409) & (13.41) & (15.091) \\
\hline \multirow[t]{2}{*}{ MB } & $-0.006^{* *}$ & $-0.006^{* *}$ & $-0.007^{* *}$ & $0.004^{*}$ & $0.006^{\star *}$ & 0.001 \\
\hline & $(-2.129)$ & $(-2.250)$ & $(-2.336)$ & -1.957 & -2.514 & -0.488 \\
\hline \multirow[t]{2}{*}{ LEVERAGE } & $-0.214^{\star \star *}$ & $-0.210^{\star * *}$ & $-0.203^{\star * *}$ & $-0.232^{\star * *}$ & $-0.216^{\star * *}$ & $-0.214^{* * *}$ \\
\hline & $(-4.990)$ & $(-4.888)$ & $(-4.713)$ & $(-6.191)$ & $(-5.806)$ & $(-5.679)$ \\
\hline \multirow[t]{2}{*}{$P P \& E$} & $-0.140^{\star *}$ & $-0.146^{* *}$ & $-0.151^{\star *}$ & $-0.103^{* * *}$ & -0.035 & 0.03 \\
\hline & $(-2.267)$ & $(-2.391)$ & $(-2.475)$ & $(-3.958)$ & $(-1.149)$ & -0.803 \\
\hline \multirow[t]{2}{*}{$\mathrm{R} \& \mathrm{D}$} & $-0.524^{* *}$ & $-0.561^{\star * *}$ & $-0.511^{* *}$ & $0.926^{* * *}$ & $0.416^{* * *}$ & $0.221^{*}$ \\
\hline & $(-2.573)$ & $(-2.725)$ & $(-2.548)$ & (8.207) & $(3.588)$ & $(1.77)$ \\
\hline \multirow[t]{2}{*}{ ROA } & -0.086 & -0.09 & -0.094 & $0.292^{\star * \star}$ & $0.250^{* * *}$ & $0.196^{* * *}$ \\
\hline & $(-1.481)$ & $(-1.555)$ & $(-1.637)$ & $(5.088)$ & $(4.387)$ & $(3.406)$ \\
\hline \multirow[t]{2}{*}{$\mathrm{ADV}$} & -0.111 & -0.112 & -0.16 & $0.884^{\star * *}$ & $0.461^{\star * *}$ & $0.376^{* * *}$ \\
\hline & $(-0.389)$ & $(-0.391)$ & $(-0.475)$ & $(6.075)$ & $(3.277)$ & $(2.65)$ \\
\hline \multirow[t]{2}{*}{ EXACCR } & $0.199^{* * *}$ & $0.196^{* * *}$ & $0.193^{* * *}$ & $0.072^{\star * *}$ & $0.147^{\star * *}$ & $0.181^{\star * *}$ \\
\hline & $(5.382)$ & $(5.312)$ & (5.29) & $(4.646)$ & $(8.341)$ & (9.995) \\
\hline \multirow[t]{2}{*}{ MTR } & $0.106^{* *}$ & $0.105^{\star \star}$ & $0.103^{\star *}$ & $0.059^{\star}$ & $0.080^{* *}$ & $0.120^{* * *}$ \\
\hline & $(2.38)$ & $(2.354)$ & $(2.305)$ & (1.655) & $(2.241)$ & $(3.296)$ \\
\hline CEO FE & YES & YES & YES & NO & NO & NO \\
\hline Industry FE & FF12 & FF49 & 4-digit SIC & FF12 & FF49 & 4-digit SIC \\
\hline Year FE & YES & YES & YES & YES & YES & YES \\
\hline Adj. $R^{2}$ & 0.683 & 0.684 & 0.685 & 0.127 & 0.174 & 0.271 \\
\hline $\mathrm{N}$ & 12,992 & 12,992 & 12,992 & 12,992 & 12,992 & 12,992 \\
\hline
\end{tabular}

Table 3 exhibits the regression results of the relationship between corporate social policy and external market condition using Heteroscedasticity Consistent Standard Error (HCSE) and controlling full covariates. The dependent variable is the weighted sum of KLD scores. The data used for the regressions consist of observations of firms covered by KLD Research \& Analytics, Inc. (KLD) SOCRATES database over the period between 1995 and 2013. The t-statistics are in the parentheses denoted by ${ }^{* * *},{ }^{* *}$ and ${ }^{*}$ for the significance levels at the $1 \%, 5 \%$ and $10 \%$, respectively. 
Table 4. CSP and external market conditions by OLS controlling for less covariates.

\begin{tabular}{|c|c|c|c|c|c|}
\hline & \multicolumn{5}{|c|}{ OLS } \\
\hline & (1) & (2) & (3) & (4) & (5) \\
\hline \multirow[t]{2}{*}{ HHI } & $-0.170^{* *}$ & $-0.175^{\star * *}$ & $-0.196^{* * *}$ & $-0.074^{* * *}$ & -0.003 \\
\hline & $(-2.544)$ & $(-2.624)$ & $(-3.116)$ & $(-2.907)$ & $(-0.149)$ \\
\hline \multirow[t]{2}{*}{ COEFF } & $-0.091^{\star * *}$ & $-0.097^{\star * *}$ & $-0.095^{\star * *}$ & $-0.137^{\star * *}$ & $-0.132^{\star * *}$ \\
\hline & $(-4.540)$ & $(-4.795)$ & $(-5.000)$ & $(-7.919)$ & $(-7.598)$ \\
\hline \multirow[t]{2}{*}{ STD } & $0.195^{\star * *}$ & $0.195^{\star * *}$ & $0.093^{* * *}$ & $0.123^{\star * *}$ & $0.086^{* * *}$ \\
\hline & $(5.36)$ & (5.363) & $(2.858)$ & $(4.046)$ & $(2.808)$ \\
\hline \multirow[t]{2}{*}{$\mathrm{AT}$} & $-0.045^{\star * *}$ & $-0.050^{\star * *}$ & $0.074^{\star \star \star}$ & $0.062^{\star \star \star *}$ & $0.055^{\star \star \star}$ \\
\hline & $(-3.341)$ & $(-3.644)$ & -22.451 & -20.836 & -19.208 \\
\hline \multirow[t]{2}{*}{ MB } & $-0.009^{*}$ & $-0.010^{* *}$ & $0.017^{\star * *}$ & $0.028^{\star * *}$ & $0.030^{\star * *}$ \\
\hline & $(-1.854)$ & $(-2.083)$ & $(4.615)$ & $(7.919)$ & $(8.855)$ \\
\hline \multirow[t]{2}{*}{ LEVERAGE } & 0.004 & 0.02 & $-0.176^{\star \star \star}$ & $-0.147^{\star * *}$ & $-0.179^{* * *}$ \\
\hline & $(0.094)$ & $(0.455)$ & $(-6.529)$ & $(-6.079)$ & $(-7.812)$ \\
\hline CEO FE & Yes & NO & NO & NO & NO \\
\hline $\mathrm{CEO}^{\star}$ Firm FE & $\mathrm{NO}$ & Yes & NO & NO & $\mathrm{NO}$ \\
\hline Industry FE & 4-digit SIC & 4-digit SIC & 4-digit SIC & FF49 & FF12 \\
\hline Year FE & Yes & Yes & Yes & Yes & Yes \\
\hline Adj. $R^{2}$ & 0.673 & 0.676 & 0.22 & 0.142 & 0.105 \\
\hline $\mathrm{N}$ & 16,911 & 16,911 & 17,803 & 17,803 & 17,803 \\
\hline
\end{tabular}

Table 4 exhibits the regression results of the relationship between corporate social policy and external market condition using OLS and controlling main explanatory variables of interest. The data used for the regressions consist of observations of firms covered by KLD Research \& Analytics, Inc. (KLD) SOCRATES database over the period between 1995 and 2013. The t-statistics are in the parentheses denoted by ${ }^{* * *}, * *$ and ${ }^{*}$ for the significance levels at the $1 \%, 5 \%$ and $10 \%$, respectively.

Table 5. CSP and external market conditions by HCSE controlling for less covariates.

\begin{tabular}{cccccc}
\hline & \multicolumn{5}{c}{ HCSE } \\
\cline { 2 - 6 } & $(1)$ & $(2)$ & $(3)$ & $(4)$ & $(5)$ \\
\hline HHI & $-0.170^{* *}$ & $-0.175^{* * *}$ & $-0.196^{* * *}$ & $-0.074^{* * *}$ & -0.003 \\
& $(-2.544)$ & $(-2.624)$ & $(-3.116)$ & $(-2.907)$ & $(-0.149)$ \\
COEFF & $-0.091^{* * *}$ & $-0.097^{* * *}$ & $-0.095^{* * *}$ & $-0.137^{* * *}$ & $-0.132^{* * *}$ \\
& $(-4.540)$ & $(-4.795)$ & $(-5.000)$ & $(-7.919)$ & $(-7.598)$ \\
STD & $0.195^{* * *}$ & $0.195^{* * *}$ & $0.093^{* * *}$ & $0.123^{* * *}$ & $0.086^{* * *}$ \\
& $(5.36)$ & $(5.363)$ & $(2.858)$ & $(4.046)$ & $(2.808)$ \\
AT & $-0.045^{* * *}$ & $-0.050^{* * *}$ & $0.074^{* * *}$ & $0.062^{* * *}$ & $0.055^{* * *}$ \\
& $(-3.341)$ & $(-3.644)$ & -22.451 & -20.836 & -19.208 \\
MB & $-0.009^{*}$ & $-0.010^{* *}$ & $0.017^{* * *}$ & $0.028^{* * *}$ & $0.030^{* * *}$ \\
& $(-1.854)$ & $(-2.083)$ & $(4.615)$ & $(7.919)$ & $(8.855)$ \\
\hline
\end{tabular}




\section{Continued}

\begin{tabular}{cccccc}
\hline LEVERAGE & 0.004 & 0.02 & $-0.176^{* * *}$ & $-0.147^{* * *}$ & $-0.179^{* * *}$ \\
& $(0.094)$ & $(0.455)$ & $(-6.529)$ & $(-6.079)$ & $(-7.812)$ \\
CEO FE & Yes & NO & NO & NO & NO \\
CEO ${ }^{*}$ Firm FE & NO & Yes & NO & NO & NO \\
Industry FE & 4-digit SIC & 4 -digit SIC & 4 -digit SIC & FF49 & FF12 \\
Year FE & Yes & Yes & Yes & Yes & Yes \\
Adj.R & 0.673 & 0.676 & 0.22 & 0.142 & 0.105 \\
$\mathrm{~N}$ & 16,911 & 16,911 & 17,803 & 17,803 & 17,803 \\
\hline
\end{tabular}

Table 5 exhibits the regression results of the relationship between corporate social policy and external market condition using Heteroscedasticity Consistent Standard Error (HCSE) and controlling main explanatory variables of interest. The dependent variable is the weighted sum of KLD scores. The data used for the regressions consist of observations of firms covered by KLD Research \& Analytics, Inc. (KLD) SOCRATES database over the period between 1995 and 2013. The t-statistics are in the parentheses denoted by ${ }^{* *},{ }^{* *}$ and ${ }^{*}$ for the significance levels at the $1 \%, 5 \%$ and $10 \%$, respectively.

\section{Concluding Remarks}

Building upon studies on the CEO-centric influence upon corporate social responsibility (see, for example, Fernández-Kranz and Santaló, 2010, Kang, 2017, Brick and Qiao, 2017, and Bernard, Godard, and Zouaoui, 2018), the paper steps further to analyze the strategic decision making of CEO in face of different market conditions. Consistent with the extant literature of organizational management, I identify three orthogonal dimensions of external market conditions: market complexity, munificence and dynamism. In the theoretical work of the paper, I develop a modeling framework in which the relationship between external market conditions and CSR engagements are identified. Accordingly, the testable hypotheses are proposed and econometric specification is formulated based on the reduced form equation of comparative statics. Consistent with extant literature, I identify the net positive influence of market competitiveness upon the level of CSR provisions. Moreover, I found that firms operating in favorable market conditions are reluctant to investment in CSR activities, while firms facing uncertain market conditions are more motivated to participate in socially responsible activities, suggesting that CSR activities are in fact value relevant and CEO is strategically utilizing CSR to maximize her own utility according to the external market conditions.

The theoretical implications and empirical findings of the paper are of great significance both for policy makers and practitioners. To promote a socially responsible economy, the regulatory authority should pay attention to the external business environment in which firms operate, which may have vital impact upon the CSR provisions. Moreover, provided that the firm's social policy and CSR initiatives are largely dictated by the CEO, appropriate internal monitoring mechanism should be in place to mitigate the concern of self-serving behaviors and non-pecuniary consumption through philanthropic activities. One potential de- 
ficiency of this study is the lack of natural experiment in the empirical tests as the identification strategy. Future empirical works could be done to untie the Gordian knot of endogeneity and further validate the theoretical implications. Specializing the theoretical framework or adding stylized features is another promising direction for future theoretical works on the determinants and value-relevancy of CSR.

\section{Acknowledgements}

The author would like to thank Feng Gao and Spring 2018 cohort of Ph.D. Seminar in Accounting Research at Rutgers Business School for helpful comments and suggestions. Any errors may be unintentional and are solely the responsibility of the author.

\section{Conflicts of Interest}

The author declares no conflicts of interest regarding the publication of this paper.

\section{References}

Agle, B. R., Mitchell, R. K., \& Sonnenfeld, J. A. (1999). Who Matters to CEOs? An Investigation of Stakeholder Attributes and Salience, Corporate Performance, and CEO Values. Academy of Management Journal, 42, 507-525. https://doi.org/10.5465/256973

Aldrich, H. E. (1979). Organizations and Environments. Englewood Cliffs, NJ: PrenticeHall.

Andreoni, J. (1989). Giving with Impure Altruism: Applications to Charity and Ricardian Equivalence. Journal of Political Economy, 97, 1447-1458. https://doi.org/10.1086/261662

Andreoni, J. (1990). Impure Altruism and Donations to Public Goods: A Theory of Warm-Glow Giving. The Economic Journal, 100, 464-477. https://doi.org/10.2307/2234133

Bae, K. H., Kang, J. K., \& Wang, J. (2011). Employee Treatment and Firm Leverage: A Test of the Stakeholder Theory of Capital Structure. Journal of Financial Economics, 100, 130-153. https://doi.org/10.1016/j.jfineco.2010.10.019

Bagnoli, M., \& Watts, S. G. (2003). Selling to Socially Responsible Consumers: Competition and the Private Provision of Public Goods. Journal of Economics \& Management Strategy, 12, 419-445. https://doi.org/10.1162/105864003322309536

Barney, J. (1991). Firm Resources and Sustained Competitive Advantage. Journal of Management, 17, 99-120. https://doi.org/10.1177/014920639101700108

Berle, A., \& Means, G. (1932). The Modern Corporation and Private Property (2nd ed., pp. 45-53). New York: Macmillan.

Bernard, Y., Godard, L., \& Zouaoui, M. (2018). The Effect of CEOs' Turnover on the Corporate Sustainability Performance of French Firms. Journal of Business Ethics, 150, 1049-1069. https://doi.org/10.1007/s10551-016-3178-7

Bolton, R. N., \& Drew, J. H. (1991). A Multistage Model of Customers' Assessments of Service Quality and Value. Journal of Consumer Research, 17, 375-384.

https://doi.org/10.1086/208564 
Brick, E. I., \& Qiao, Y. (2017). CEO Turnover and Corporate Social Responsibility. Boston: Academy of Business Research. https://www.aobronline.com

Brown, T. J., \& Dacin, P. A. (1997). The Company and the Product: Corporate Associations and Consumer Product Responses. The Journal of Marketing, 61, 68-84. https://doi.org/10.1177/002224299706100106

Cordeiro, J. J., \& Tewari, M. (2015). Firm Characteristics, Industry Context, and Investor Reactions to Environmental CSR: A Stakeholder Theory Approach. Journal of Business Ethics, 130, 833-849. https://doi.org/10.1007/s10551-014-2115-x

Deckop, J. R., Merriman, K. K., \& Gupta, S. (2006). The Effects of CEO Pay Structure on Corporate Social Performance. Journal of Management, 32, 329-342. https://doi.org/10.1177/0149206305280113

Dess, G. G., \& Beard, D. W. (1984). Dimensions of Organizational Task Environments. Administrative Science Quarterly, 29, 52-73. https://doi.org/10.2307/2393080

Fang, E., Palmatier, R. W., \& Steenkamp, J. B. E. (2008). Effect of Service Transition Strategies on Firm Value. Journal of Marketing, 72, 1-14. https://doi.org/10.1509/jmkg.72.5.001

Fernández-Kranz, D., \& Santaló, J. (2010). When Necessity Becomes a Virtue: The Effect of Product Market Competition on Corporate Social Responsibility. Journal of Economics \& Management Strategy, 19, 453-487. https://doi.org/10.1111/j.1530-9134.2010.00258.x

Fisman, R., Heal, G., \& Nair, V. (2006). A Model of Corporate Philanthropy. New York: Columbia University and University of Pennsylvania.

Godfrey, P. C., Merrill, C. B., \& Hansen, J. M. (2009). The Relationship between Corporate Social Responsibility and Shareholder Value: An Empirical Test of the Risk Management Hypothesis. Strategic Management Journal, 30, 425-445. https://doi.org/10.1002/smj.750

Guiso, L., \& Paiella, M. (2008). Risk Aversion, Wealth, and Background Risk. Journal of the European Economic Association, 6, 1109-1150. https://doi.org/10.1162/JEEA.2008.6.6.1109

Hill, C. W., \& Hoskisson, R. E. (1987). Strategy and Structure in the Multiproduct Firm. Academy of Management Review, 12, 331-341. https://doi.org/10.5465/amr.1987.4307949

Hitt, M. A., \& Ireland, R. D. (1985). Corporate Distinctive Competence, Strategy, Industry and Performance. Strategic Management Journal, 6, 273-293. https://doi.org/10.1002/smj.4250060307

Jensen, M. C., \& Meckling, W. H. (1979). Theory of the Firm: Managerial Behavior, Agency Costs, and Ownership Structure. In Economics Social Institutions (pp. 163-231). Dordrecht: Springer. https://doi.org/10.1007/978-94-009-9257-3_8

Kang, J. (2017). Unobservable CEO Characteristics and CEO Compensation as Correlated Determinants of CSP. Business \& Society, 56, 419-453.

https://doi.org/10.1177/0007650314568862

Keats, B. W., \& Hitt, M. A. (1988). A Causal Model of Linkages among Environmental Dimensions, Macro Organizational Characteristics, and Performance. Academy of Management Journal, 31, 570-598. https://doi.org/10.2307/256460

Khandwalla, P. N. (1973). Effect of Competition on the Structure of Top Management Control. Academy of Management Journal, 16, 285-295. https://doi.org/10.5465/255329

Lins, K. V., Servaes, H., \& Tamayo, A. (2017). Social Capital, Trust, and Firm Perfor- 
mance: The Value of Corporate Social Responsibility during the Financial Crisis. The Journal of Finance, 72, 1785-1824. https://doi.org/10.1111/jofi.12505

Lovell, M. C. (1986). Tests of the Rational Expectations Hypothesis. The American Economic Review, 76, 110-124.

Luo, X., \& Bhattacharya, C. B. (2009). The Debate over Doing Good: Corporate Social Performance, Strategic Marketing Levers, and Firm-Idiosyncratic Risk. Journal of Marketing, 73, 198-213. https://doi.org/10.1509/jmkg.73.6.198

McWilliams, A., \& Siegel, D. (2001). Corporate Social Responsibility: A Theory of the Firm Perspective. Academy of Management Review, 26, 117-127. https://doi.org/10.5465/amr.2001.4011987

Muth, J. F. (1961). Rational Expectations and the Theory of Price Movements. Econometrica: Journal of the Econometric Society, 29, 315-335. https://doi.org/10.2307/1909635

Oliver, R. L. (1980). A Cognitive Model of the Antecedents and Consequences of Satisfaction Decisions. Journal of Marketing Research, 17, 460-469.

https://doi.org/10.1177/002224378001700405

Starbuck, W. H. (1976). Organizations and Their Environments. In M. D. Dunette (Ed.), Handbook of Industrial and Organisational Psychology (pp. 1069-1124). Chicago, IL: Rand McNally Publishers.

Szymanski, D. M., \& Henard, D. H. (2001). Customer Satisfaction: A Meta-Analysis of the Empirical Evidence. Journal of the Academy of Marketing Science, 29, 16-35. https://doi.org/10.1177/0092070301291002

Udayasankar, K. (2008). Corporate Social Responsibility and Firm Size. Journal of Business Ethics, 83, 167-175. https://doi.org/10.1007/s10551-007-9609-8

Wernerfelt, B. (1984). A Resource-Based View of the Firm. Strategic Management Journal, 5, 171-180. https://doi.org/10.1002/smj.4250050207

Williamson, O. E. (1965). A Dynamic Theory of Interfirm Behavior. The Quarterly Journal of Economics, 79, 579-607. https://doi.org/10.2307/1880653

Zhang, R., Zhu, J., Yue, H., \& Zhu, C. (2010). Corporate Philanthropic Giving, Advertising Intensity, and Industry Competition Level. Journal of Business Ethics, 94, 39-52. https://doi.org/10.1007/s10551-009-0248-0 


\section{Appendix A: Comparative Statics}

As developed in the previous section, the first order condition for the partial equilibrium of firm $i$ in a certain business sector can be expressed in the following notation,

$$
(P(\kappa)-C) X_{C S P}(\kappa)+\lambda(\mu)\left(-\frac{1}{2} V_{C S P}(\theta)\right)=C_{C S P}
$$

in which $X_{C S P}=\frac{\partial X}{\partial C S P}, \quad V_{C S P}=\frac{\partial V}{\partial C S P}, \quad C_{C S P}=\frac{\partial C_{c s p}}{\partial C S P}$, and $\kappa, \mu, \theta$ are exogenously given parameters of environmental dimensions for competition, munificence and dynamism, respectively. The main interest of the research is to examine how CEO strategically deploys social policy in response to different environmental conditions across three dimensions. To guide the empirical predications, I derive the comparative statics from the above analytical framework, whereby taking total differentiation of the first order condition (5) with respect to $\kappa, \mu, \theta$ and CSP, as follows.

$$
\mathrm{d}(P(\kappa)-C) X_{C S P}(\kappa)-\mathrm{d} C_{C S P}+\mathrm{d} \lambda(\mu)\left(-\frac{1}{2} \sigma_{C S P}^{2}(\theta)\right)=0
$$

in which,

$$
\begin{gathered}
\mathrm{d}(P(\kappa)-C) X_{C S P}(\kappa)=\left(\frac{\partial P}{\partial \kappa} X_{C S P}+\frac{\partial X_{C S P}}{\partial \kappa}(P-C)\right) \mathrm{d} \kappa \\
\mathrm{d} C_{C S P}=\left((P-C) \frac{\partial X_{C S P}}{\partial C S P}+\lambda(\mu)\left(-\frac{1}{2} \frac{\partial \sigma_{C S P}^{2}}{\partial C S P}\right)-C_{C S P}^{\prime \prime}\right) \mathrm{d} C S P \\
\mathrm{~d} \lambda(\mu)\left(-\frac{1}{2} \sigma_{C S P}^{2}(\theta)\right)=\left(\frac{\partial \lambda}{\partial \mu}\left(-\frac{1}{2} \sigma_{C S P}^{2}\right)\right) \mathrm{d} \mu \\
\mathrm{d} \lambda(\mu)\left(-\frac{1}{2} \sigma_{C S P}^{2}(\theta)\right)=\lambda\left(-\frac{1}{2} \frac{\partial \sigma_{C S P}^{2}}{\partial \theta}\right) \mathrm{d} \theta
\end{gathered}
$$

Specifically, according to Fernández-Kranz and Santaló (2010), $\frac{\partial P}{\partial \kappa}$ is negative due to the marginal effect brought by the market competition on the profit margin, and $\frac{\partial X_{C S P}}{\partial \kappa}$ is positive due to the business stealing effect of CSR provisions embedded in the private products. Business stealing effect proposed in the analytical work of Fernández-Kranz and Santaló (2010) is consistent with the "egoistic" preferences in Andreoni (1989, 1990), in the sense that rational and selfish consumers experience the favorable "warm glow" from purchasing goods produced by socially-responsible firms. Since the demand function $X\left(P_{1}, P_{2}, \cdots, P_{i}, \cdots, \operatorname{CSP}_{i}, \cdots, \operatorname{CSP}_{n}\right)$ is twice continuous differentiable and strictly concave with respect to $C S P, \frac{\partial X_{C S P}}{\partial C S P}$ is negative. Similarly, following the economic convention of diminishing marginal gain, I assume the functional form of $\sigma^{2}$ is twice differentiable and strictly concave with respect to CSP, and thus 
$\frac{\partial V_{C S P}}{\partial C S P}$ is negative. The environmental dimension of munificence measures the degree of generosity of endowment and abundancy of growth opportunity provided by the industrial segment. Intuitively, having been in face of a promising market perspective, $\mathrm{CEO}$ is more likely to take on risky investment strategies and thus demonstrate less risk aversion. Moreover, the idea of variable risk aversion over different regimes and backgrounds is supported by increasing empirical evidence (see, for example, Guiso and Paiella, 2008). Thus, I assume a strictly decreasing functional form of risk aversion with respect to munificence, $\frac{\partial \lambda}{\partial \mu}<0$. In consistent with the classic assumption on cost-production function, I assume the additional cost incurred by CSR provisions is twice continuous differentiable, strict increasing and convex with respect to CSP, $C_{C S P}^{\prime \prime}>0$.

To simplify the notation, let $\frac{\partial P}{\partial \kappa}=P_{\kappa}, \frac{\partial \lambda}{\partial \mu}=\lambda_{\mu}, \frac{\partial X_{C S P}}{\partial C S P}=X_{C S P}^{\prime \prime}$, and $\frac{\partial V_{C S P}}{\partial C S P}=V_{C S P}^{\prime \prime}$. The comparative statics for the dynamics of CSP in face of changes in exogenous environmental factors, complexity $(\kappa)$, munificence $(\mu)$, and dynamism $(\theta)$ can be derived as follows.

$$
\begin{aligned}
& \frac{\mathrm{d} C S P}{\mathrm{~d} \kappa}=-\frac{P_{\kappa} X_{C S P}+\frac{\partial X_{C S P}}{\partial \kappa}(P-C)}{(P-C) X_{C S P}^{\prime \prime}+\lambda(\mu)\left(-\frac{1}{2} V_{C S P}^{\prime \prime}\right)-C_{C S P}^{\prime \prime}}<>0 \\
& \frac{\mathrm{d} C S P}{\mathrm{~d} \mu}=-\frac{\lambda_{\mu}\left(-\frac{1}{2} V_{C S P}\right)}{(P-C) X_{C S P}^{\prime \prime}+\lambda(\mu)\left(-\frac{1}{2} V_{C S P}^{\prime \prime}\right)-C_{C S P}^{\prime \prime}}<0 \\
& \frac{\mathrm{d} C S P}{\mathrm{~d} \theta}=-\frac{\left.1-\frac{\partial}{2} \frac{\partial V_{C S P}}{\partial \theta}\right)}{(P-C) X_{C S P}^{\prime \prime}+\lambda(\mu)\left(-\frac{1}{2} V_{C S P}^{\prime \prime}\right)-C_{C S P}^{\prime \prime}}>0
\end{aligned}
$$

Obviously, the denominators of all above equations are negative and the sign of the comparative statics is dependent on the numerator. In particular, due to the opposite forces of profit marginal effect and business stealing effect brought by the competition or complexity parameter $(\kappa)$, the sign of the first comparative static is unclear in the sense that different theoretical architecture could lead to the different aggregate effect of $\kappa$ and it therefore becomes an empirical problem. The sign of the other two comparative statics pertaining to the exogenous change of munificence $(\mu)$ and dynamism $(\theta)$ is readily determined based on the settings of the analytical framework.

\section{Appendix B: Graphical Analysis}

The derivation of above comparative statics could also be illustrated using the graphical approach, in which the process of reaching new equilibrium after the 
shock on the exogenous parameters is clearly outlined. For exhibition purpose, I adopt the following notations.

$$
\begin{gathered}
(P(\kappa)-C) X_{C S P}(\kappa)=\mathrm{K}(\kappa, C S P) \\
\lambda(\mu)\left(-\frac{1}{2} V_{C S P}(\theta)\right)=\Theta \mathrm{M}(\theta, \mu, C S P)
\end{gathered}
$$

As shown in Figure 1, the shift of curve $\mathrm{K}(\kappa, C S P)$ is dependent on the aggregate influence of the exogenous shock on the environmental dimension of market complexity. The power of two opposite forces, marginal effect and business stealing effect, is subject to the specific modeling structure and assumptions and therefore cannot be determined in the current analytical framework.

Figure 2 demonstrates the path in which level of CSR provisions moves from initial condition $\left(C S P^{*}\right)$ to the new equilibrium $\left(C S P^{* *}\right)$ in face of the variation of the exogenous environmental parameter of munificence $(\mu)$. As developed in the previous section, the risk aversion of CEO is negatively related to munificence, which measures the generosity and abundancy of the resources and growth potential supported by the external business environment. Thus, in reaction to a incremental shock upon munificence $(\mu)$, the curve $\Theta \mathrm{M}(\theta, \mu, C S P)$ will move downward, leading to an new equilibria in which the level of CSR provisions chosen by the CEO is $C S P^{* *}$. As developed in the previous sections, the additional fixed cost incurred by CSP is twice continuous differentiable and strict non-concave, $C_{C S P}^{\prime \prime} \geq 0$ and the demand $X(*)$ is twice continuous differentiable and strict concave in CSP, $X_{C S P}^{\prime \prime}<0$. Thus, the curve of $C_{c s p}-\mathrm{K}(\kappa, C S P)$ should be increasing in CSP due to the fact that

$\frac{\partial\left(C_{c s p}-\mathrm{K}(\kappa, C S P)\right)}{\partial C S P}=C_{C S P}^{\prime \prime}-(P(\kappa)-C) X_{C S P}^{\prime \prime}(\kappa)>0$. Therefore, clearly the new equilibrium condition $C S P^{* *}$ should be less than the previous equilibria $C S P^{*}$ as demonstrated in the above figure.

Figure 3 shows how the equilibrium is updated in face of the incremental shock upon market dynamism $(\theta)$. I can perform analogous analysis to that of Figure 2, except that the shift of curve $\Theta \mathrm{M}(\theta, \mu, C S P)$ is upward and result in a new equilibrium with higher level of CSR provisions $\left(\operatorname{CSP} P^{* *}\right)$.

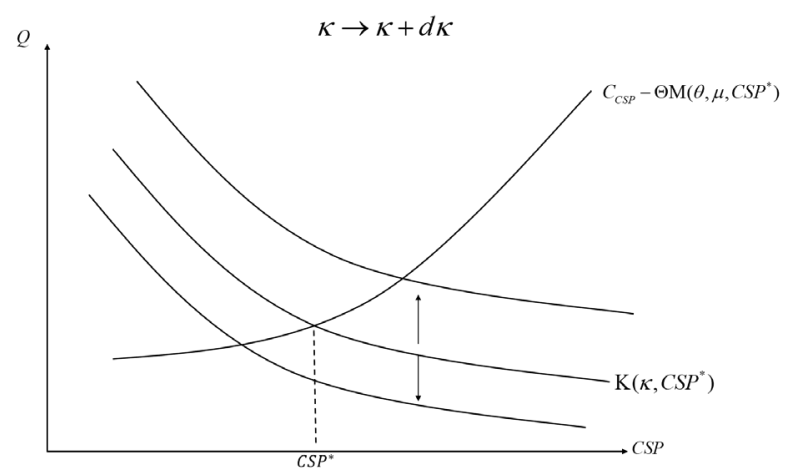

Figure 1. CSP change in face of varied market complexity. 


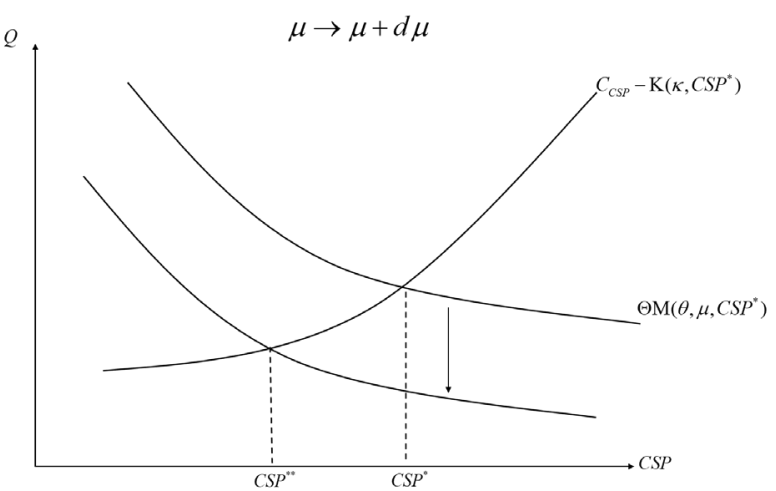

Figure 2. CSP change in face of varied market munificense.

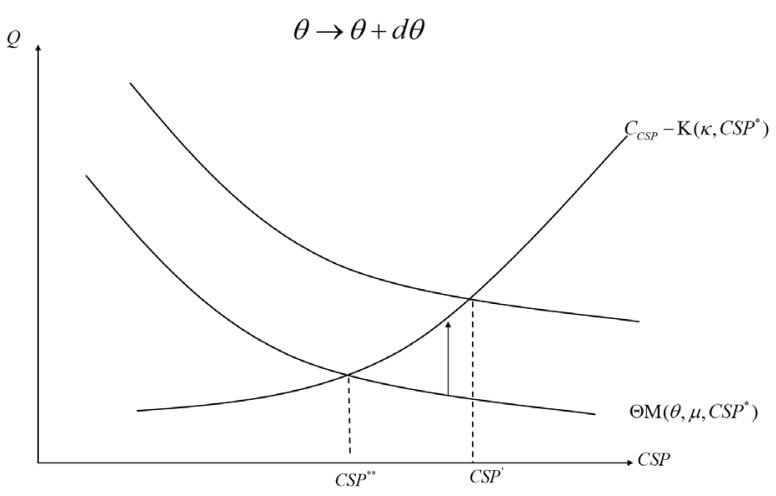

Figure 3. CSP change in face of varied market dynaism. 